\title{
EL NIÑO-SOUTHERN OSCILLATION INFLUENCES ON THE MAHAWELI STREAMFLOW IN SRI LANKA
}

\author{
LAREEF ZUBAIR* \\ International Research Institute for Climate Prediction, Lamont Doherty Earth Observatory of Columbia University, PO Box 1000, \\ Palisades, NY 10964-8000, USA \\ Received 16 July 2001 \\ Revised 4 September 2002 \\ Accepted 4 September 2002
}

\begin{abstract}
Despite advances over the last two decades in the capacity to predict the evolution of the El Niño-southern oscillation (ENSO) phenomenon and advances in understanding of the relationship between ENSO and climate, there has been little use of climate predictions for water resources management in the tropics. As part of an effort to develop such a prediction scheme, the ENSO influences on streamflow and rainfall in the upper catchment of the Mahaweli river in Sri Lanka were investigated with correlation analysis, composite analysis and contingency tables. El Niño conditions were often associated with decreased annual flows and La Niña with increased flows. The relationship of streamflow and rainfall with the ENSO index of NINO3 contrasted between January to September and October to December. During El Niño episodes the streamflow declines from January to September, but from October to December there is no clear relationship. On the other hand, rainfall shows a clear increase from October to December and declines during January, February, March, July and August. The simultaneous correlations of NINO3 with the aggregate January to September streamflow $(r=-0.50)$, with January to September rainfall $(r=-0.44)$ and with October to December rainfall $(r=0.48)$ are all significant at the $99 \%$ level. The correlation between one-season-in-advance NINO3 with both January to September streamflow and October to December rainfall remained significant at the $99 \%$ level.

This study demonstrates the potential of using ENSO-based predictors for a seasonal hydro-climatic prediction scheme in the Mahaweli basin. It shows the significant contrasts in ENSO influence on rainfall and streamflow due to various hydrological processes. It has demonstrated that the potential for prediction is improved by investigating ENSO influences for the appropriate season for the given river catchment. Copyright (c) 2003 Royal Meteorological Society.
\end{abstract}

KEY WORDS: streamflow predictions; ENSO; Sri Lanka; Mahaweli river; hydrometeorology

\section{INTRODUCTION}

The El Niño-southern oscillation (ENSO) phenomenon is now recognized as a primary mode of seasonal climatic variability, particularly in the tropics (Ropelewski and Halpert, 1987, 1989). It has become possible to forecast the ENSO phenomenon (Cane and Zebiak, 1985; Goddard et al., 2001) with some skill up to 9 months in advance. Thus, any association between ENSO and streamflow can be used for a prediction scheme to help with water resources management. Sensitivity of streamflow to ENSO has been investigated for a number of rivers (Simpson et al., 1993; Kahya and Dracup, 1993; Dracup and Kahya, 1994; Amarasekera et al., 1997; Piechota et al., 1997; Piechota and Dracup, 1996; Uvo and Graham, 1998; Wang and Eltahir, 1999; Kahya and Karabork, 2001). A comprehensive review of these and other efforts is provided in Dettinger et al. (2000) and Dettinger and Diaz (2000).

* Correspondence to: Lareef Zubair, International Research Institute for Climate Prediction, Lamont Doherty Earth Observatory of Columbia University, PO Box 1000, Palisades, NY 10964-8000, USA; e-mail: lareef@iri.columbia.edu 


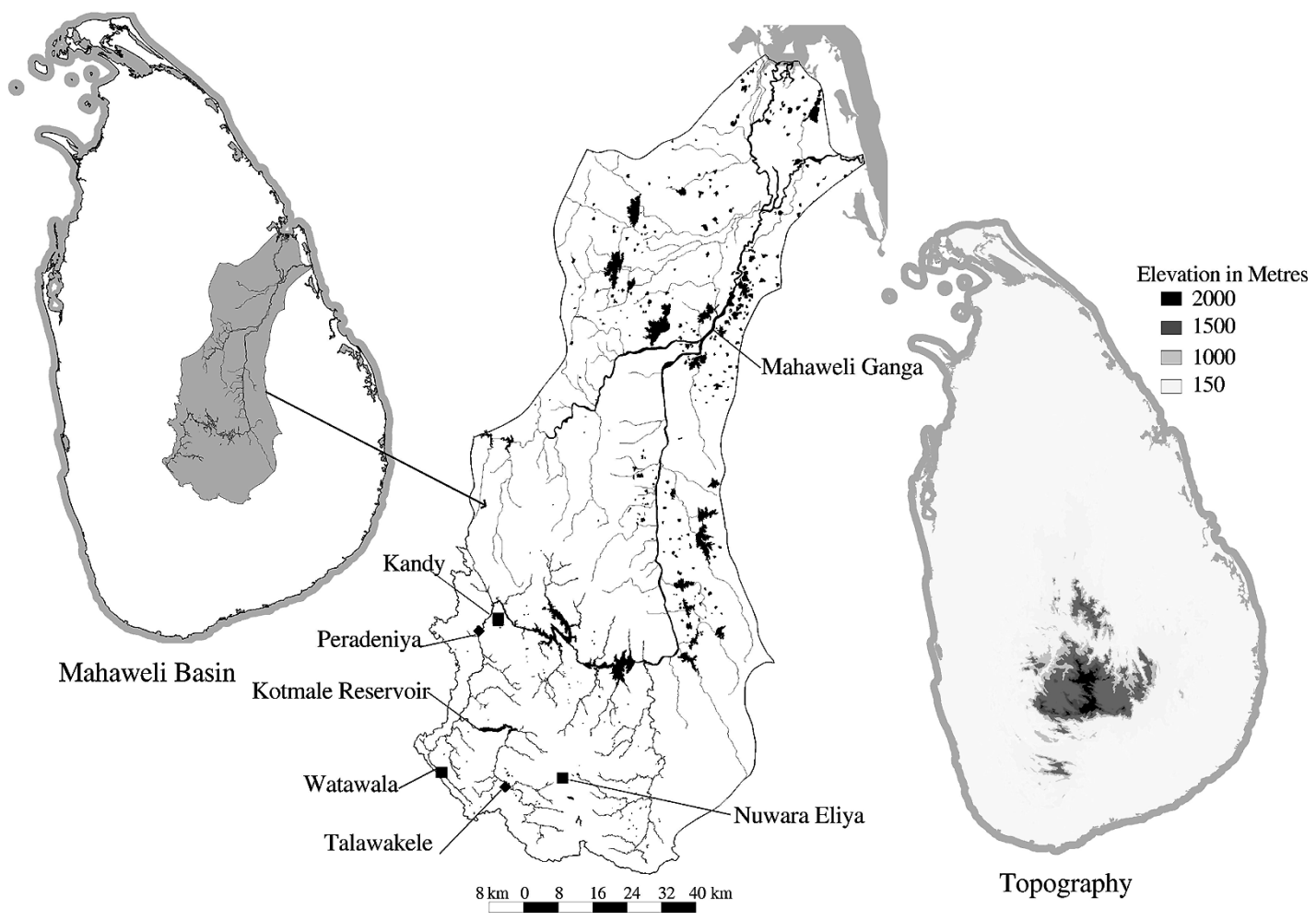

Figure 1. The Mahaweli river basin is shown on a map of Sri Lanka (left). The streamflow and rainfall measuring stations and the course of the river is identified in the enlargement of the Mahaweli basin (centre). The streamflow measuring stations at Talawakelle and Peradeniya are indicated with diamond symbols. The rainfall measuring stations at Kandy, Watawala and Nuwara Eliya are identified with square symbols. The topography of Sri Lanka is also shown (right)

One of the regions where a significant ENSO influence on rainfall and temperature has been reported is Sri Lanka (Rasmussen and Carpenter, 1983; Ropelewski and Halpert, 1989; Suppiah, 1989, 1996, 1997). In this paper, the ENSO influence on streamflow in the largest river in Sri Lanka, the Mahaweli (Figure 1), is investigated. The $331 \mathrm{~km}$ long river sweeps around the central mountain massifs capturing the discharge from tributaries on the western and eastern slopes of the highlands and then discharges to the sea to the northeast. Of the annual precipitation of $28 \times 10^{9} \mathrm{~m}^{3}$ in the Mahaweli basin of $10448 \mathrm{~km}^{2}$, only $9 \times 10^{9} \mathrm{~m}^{3}$ is discharged to the sea. Water is expended in the basin for evaporation, seepage, irrigation, municipal uptake and trans-basin diversions. In the past two decades, four dams and one barrage have been constructed to aid irrigation and hydropower generation. The streamflow is made use of to irrigate 365000 ha of rice fields in the lowlands. There are six hydropower plants fed by the Mahaweli waters with an installed capacity of $660 \mathrm{MW}$ (which is $40 \%$ of the island-wide hydropower potential). Streamflow in the Mahaweli has shown significant declines on a decadal time scale; this has been attributed to environmental causes, including deforestation (Wickramagamage, 1997). This decline has led to considerable water stress.

Advance warnings of seasonal deficits will be particularly useful for drought management through such adaptive measures as choosing less irrigation-intensive crops, reducing acreage under cultivation and thermal electricity generation instead of hydro-electricity. Advance warning of seasons with above-normal streamflow can be taken advantage of to cultivate additional rice fields and to maximize the generation of hydro-electricity.

The headstream of the Mahaweli is on the western slopes of the central highlands in Sri Lanka, which reach an altitude of $2500 \mathrm{~m}$. These western hill slopes have the highest annual rainfall in the island, reaching $6000 \mathrm{~mm}$. Indeed, whereas the upper catchment comprises only $11 \%$ of the basin area, it receives $60 \%$ of the total basin rainfall. The other major rivers in Sri Lanka, such as the Kelani, 


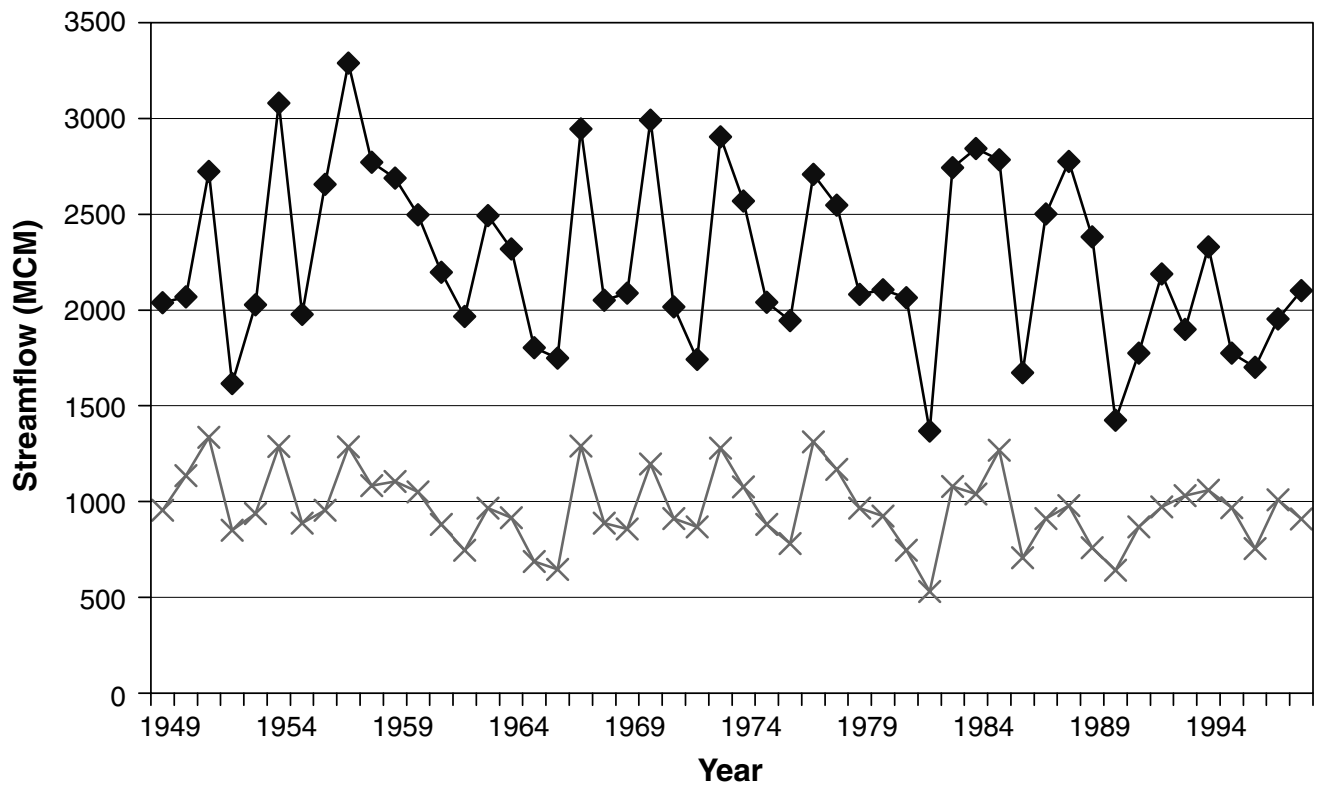

$$
\begin{aligned}
& - \text { Polgolla observations (6 km downstream of Peradeniya) } \\
& \times \quad \text { Inflow to Kotmale Reservoir ( } 6 \mathrm{~km} \text { downstream of Talawakelle) }
\end{aligned}
$$

Figure 2. The time traces of the annual (October to September) streamflow at Polgolla (6 km downstream of Peradeniya) and at the inflow to the Kotmale reservoir ( $6 \mathrm{~km}$ downstream of Talawakelle). Construction on the Kotmale reservoir started in 1985 and the river was impounded in 1988

Kalu and Walawe, which host the remaining hydropower stations, also originate in the same western highlands.

Unlike in India, the principal rainfall mechanisms are the winter monsoon, storms and depressions arriving from the adjacent seas, the inter-tropical convergence zone (ITCZ) and orographic rainfall induced by the island's topography. The winter monsoon rainfall in Sri Lanka is from the October to the December. The ITCZ-induced rainfall prevails from April to June and from September to November. The orographic rainfall is heavy from June to September in the western hill slopes that include the Upper Mahaweli catchment that is considered here. However, as seen in Figure 2, the rainfall in the Upper Mahaweli basin is all year around, with the 4-month summer period obtaining only a third of the total rainfall. Thus, unlike in India, prediction schemes for the Mahaweli cannot concentrate on the summer alone.

During El Niño events, the modulations of climate in Sri Lanka are due to the alteration in intensity and location of the large-scale equatorial circulation system referred to as the Walker cell (Allan et al., 1996). The rainfall of Sri Lanka is enhanced during El Niño events from October to December but it is diminished by them from July to August (Rasmussen and Carpenter, 1983; Suppiah, 1996) and from January to March (Zubair, 2001).

Next, the ENSO, rainfall and streamflow data are described. Thereafter, the analyses of the ENSO influences on rainfall and streamflow are presented. Finally, the main conclusions are summarized and discussed.

\section{DATA}

\subsection{ENSO data}

The sea-surface temperature (SST)-based ENSO indices NINO3 and NINO3.4 were obtained by averaging the SSTs in their respective regions of the equatorial eastern Pacific Ocean. For the NINO3 index, the 
region is $\left(5^{\circ} \mathrm{S}-5^{\circ} \mathrm{N}, 90-150^{\circ} \mathrm{W}\right)$. For the NINO3.4 index, the region is $\left(5^{\circ} \mathrm{S}\right.$ to $\left.5^{\circ} \mathrm{N}, 120-180^{\circ} \mathrm{W}\right)$. The sea surface areas for these two indices overlap, with NINO3.4 shifted towards the central Pacific. The KAPLAN data set (Kaplan et al., 1998) for SST was used. Another ENSO index, the southern oscillation index, is defined as the pressure difference between Tahiti and Darwin, Australia, and was obtained following Ropelewski and Jones (1987). The results obtained from these three indices were found to be similar.

\subsection{Rainfall data}

There is regional variability in ENSO influences on Sri Lankan rainfall (Suppiah, 1996). However, the Upper Mahaweli catchment lies entirely within a climatically homogeneous region, as identified by Puvaneswaram and Smithson (1993), and thus rainfall in different stations in the upper catchment can be considered in aggregate.

Available monthly rainfall records from 1869 to 1998 were obtained for three Sri Lanka Department of Meteorology/WMO rainfall stations that are well distributed in the Upper Mahaweli catchment. These stations are Kandy $\left(7^{\circ} 20^{\prime} \mathrm{N}, 80^{\circ} 38^{\prime} \mathrm{E}, 477 \mathrm{~m}\right.$ a.s.l.), Nuwara Eliya $\left(6^{\circ} 58^{\prime} \mathrm{N}, 80^{\circ} 46^{\prime} \mathrm{E}, 1895 \mathrm{~m}\right.$ a.s.1.), and Watawala $\left(6^{\circ} 58^{\prime} \mathrm{N}, 80^{\circ} 31^{\prime} \mathrm{E}, 960 \mathrm{~m}\right.$ a.s.1.) (Figure 1). A composite rainfall index for the upper catchment was constructed by averaging the rainfall of these stations. This composite rainfall is used for all subsequent analysis.

\subsection{Streamflow data}

For the Upper Mahaweli catchment, monthly streamflow data are available for Peradeniya from 1942 to 1993 and for Talawakelle from 1954 to 1993, as described in Table I. A small number of missing streamflow data (3\% of the record) were estimated from regression analysis with neighbouring streamflow measurement stations. The streamflow measuring site at Peradeniya enables good streamflow measurements. The most recent rating curve dates from 1976, and the streamflow measurements were calibrated up to $425 \mathrm{~m}^{3} / \mathrm{s}$ (NEDECO, 1979). Since 1988, streamflow at Peradeniya has been affected by the management of one of the tributaries leading to it at the Kotmale Dam. The analyses were repeated for the Talawakelle streamflow, which is measured above the Kotmale reservoir and is not subject to flow modifications. The influence of the construction and operation of the Kotmale reservoir since 1985 is brought out by representing the annual streamflow just upstream of the reservoir (6 km downstream of Talawakelle) and downstream of the reservoir at Polgolla $(6 \mathrm{~km}$ downstream of Peradeniya) in Figure 2. The interannual variability of streamflow at these locations was similar until the impoundment of Kotmale reservoir in 1988.

Unlike in many other locations (Dettinger and Diaz, 2000), there is hardly any lag between streamflow and rainfall seasonality (Figure 3). The usual causes of lag, such as snow melt, long times for travel down the river, underground reservoirs and strong seasonality in potential transpiration, are absent in the Upper Mahaweli.

Table I. Details of the Talawakelle and Peradeniya streamflow measuring stations on the Mahaweli river. The Kotmale reservoir is the only place where the Mahaweli is managed upstream of Peradeniya. Kotmale reservoir was impounded in 1985

\begin{tabular}{lccccc}
\hline \multirow{2}{*}{ Station } & \multirow{2}{*}{ Catchment $\left(\mathrm{km}^{2}\right)$} & \multicolumn{2}{c}{ Location } & \multirow{2}{*}{ Data duration } \\
\cline { 3 - 5 } & & Latitude $(\mathrm{N})$ & Longitude $(\mathrm{E})$ & Elevation $(\mathrm{m})$ & \\
\hline Talawakelle & 297 & $6^{\circ} 56^{\prime}$ & $80^{\circ} 39^{\prime}$ & 1200 & $1954-93$ \\
Peradeniya & 1167 & $7^{\circ} 15^{\prime}$ & $80^{\circ} 35^{\prime}$ & 463 & $1943-93$ \\
\hline
\end{tabular}




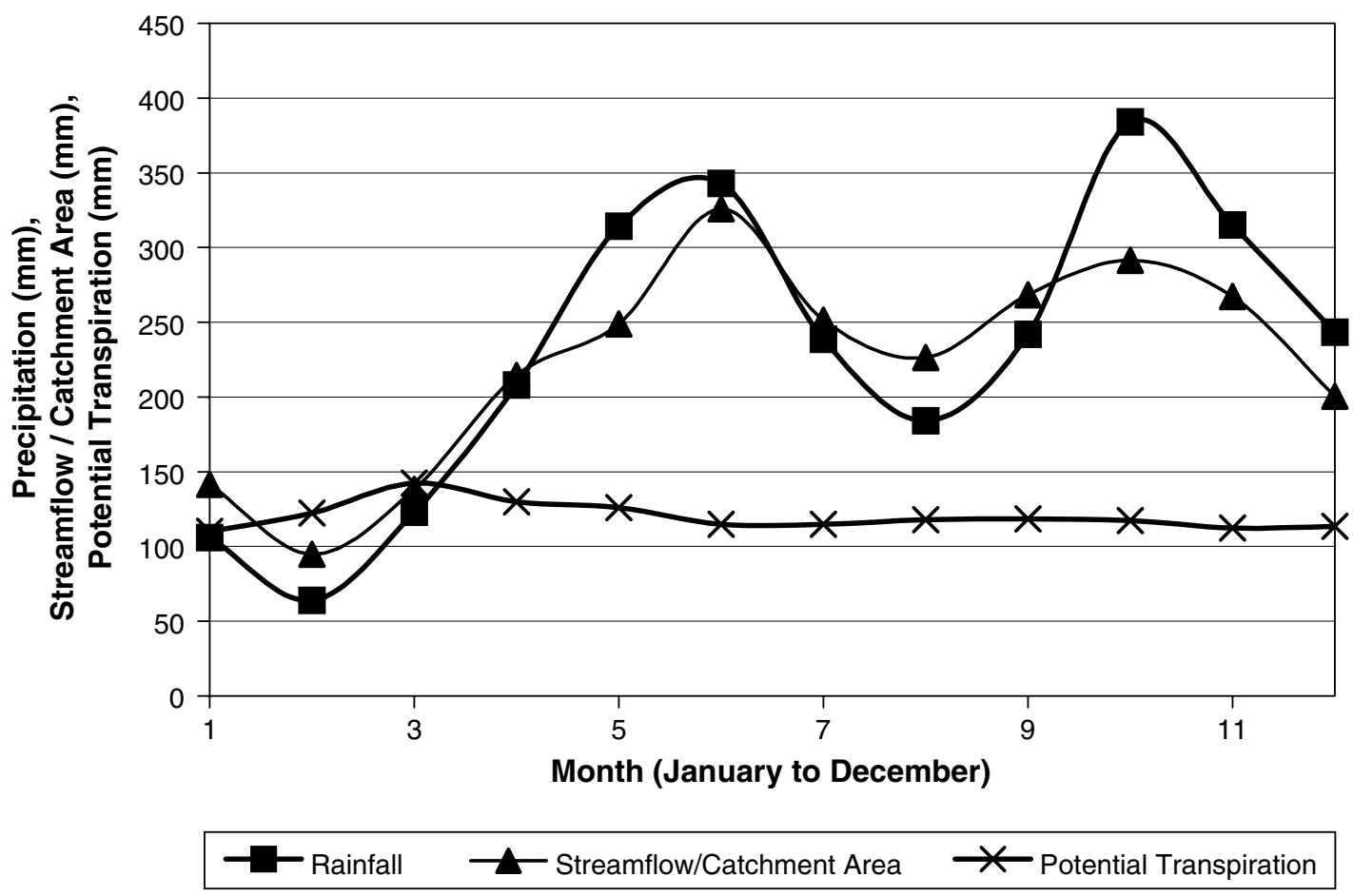

Figure 3. The seasonal cycle of catchment rainfall, Peradeniya streamflow and potential transpiration has been presented here for the Upper Mahaweli catchment. The rainfall and streamflow were estimated on records from 1943 to 1993 . The streamflow has been normalized by the catchment area at Peradeniya $\left(1167 \mathrm{~km}^{2}\right)$ and has been presented in units of millimetres for easy comparison with rainfall and potential transpiration. The potential transpiration was estimated as the average of that for Nuwara Eliya and Kandy as reported by Piper et al. (1994)

\section{RESULTS}

\subsection{Analysis of ENSO influences on rainfall in the Upper Mahaweli catchment}

The ENSO relationship with catchment rainfall during El Niño, La Niña and normal phases was brought out (Figure 4) by conditionally averaging the monthly rainfall in periods where the NINO3 index was above $0.5^{\circ} \mathrm{C}$, below $-0.5^{\circ} \mathrm{C}$ or in between these two limits respectively.

El Niño conditions were associated with a marked increase in average rainfall from October to December and a modest decline in rainfall during January, February, March, July and August. The influences on rainfall during La Niña were in the opposite sense of that for El Niño, except from January to March, when both ENSO extremes were associated with modest declines in rainfall.

During El Niño events, the summer rainfall declines in the Mahaweli basin, as during the summer monsoon period (June to September) in India (Rasmussen and Carpenter, 1983; Ropelweski and Halpert, 1987). This decline is due to large-scale anomalous subsidence over India and the central Indian Ocean region during El Niño events (Krishna Kumar et al., 1999a,b). However, from October to December the zone of subsidence is shifted northward during the autumn and is replaced with a zone of convergence near Sri Lanka leading to enhanced rainfall (Rasmussen and Carpenter, 1983; Ropelewski and Halpert, 1989; Suppiah, 1996, 1997).

3.1.1. October to December. The average rainfall from October to December shows a $15 \%$ increase during El Niño episodes and a 7\% decline during La Niña. The rainfall shows a correlation of 0.48 with the NINO3 index over the 130 year record, which is statistically significant at the $99 \%$ level (Table II). This relationship is important, as the rainfall from October to December accounts for a third of the total annual rainfall and 


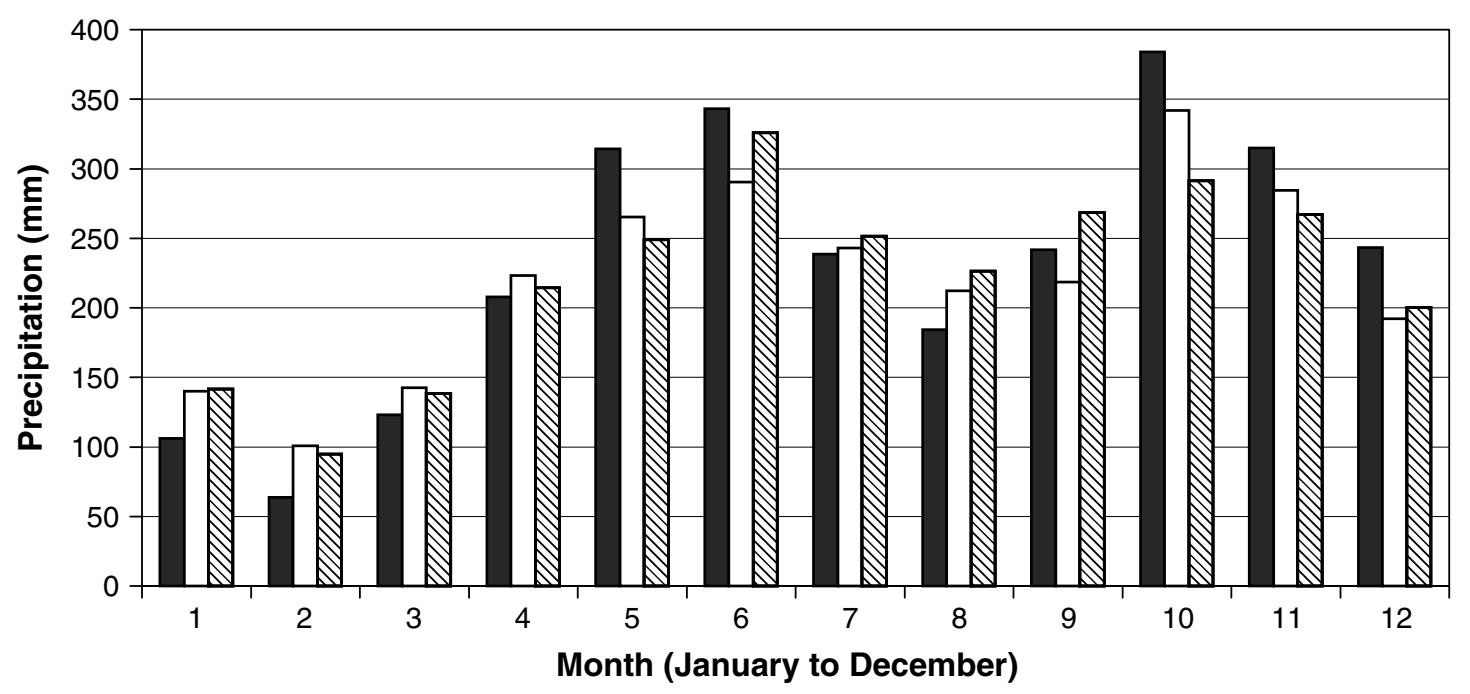

\section{$\square$ El Nino $\square$ Normal $\mathbb{Q}$ La Nina}

Figure 4. The average monthly rainfall in the Upper Mahaweli catchment during the El Niño, La Niña and normal periods based on records from 1869 to 1998

Table II. Seasonal breakdown of rainfall in the Upper Mahaweli based on records from 1869 to 1998. The correlation of rainfall with NINO3 is also tabulated by quarter. Correlations that are significant at the $99 \%$ and $95 \%$ levels are 0.22 and 0.17 respectively $(n=130)$. For the shorter record, from 1943 to 1993 , the significance levels at $99 \%$ and $95 \%$ are 0.36 and 0.28 respectively. Correlations that are significant at the $95 \%$ level are shown in bold

\begin{tabular}{lllllr}
\hline Characteristic & JFM $^{\mathrm{a}}$ & AMJ $^{\mathrm{a}}$ & JAS $^{\mathrm{a}}$ & OND $^{\mathrm{a}}$ & Annual total \\
\hline Mean rainfall (mm) & 319 & 764 & 563 & 827 & 2473 \\
Standard deviation (mm) & 118 & 163 & 169 & 180 & 285 \\
Correlation with NINO3 & & & & $\mathbf{0 . 4 8}$ & 0.10 \\
$\quad(1869-1998)$ & -0.17 & -0.18 & $\mathbf{- 0 . 2 2}$ & $\mathbf{0 . 3 6}$ & -0.20 \\
$\quad(1943-93)$ & -0.24 & -0.03 & -0.25 & \\
\hline
\end{tabular}

a JFM: January-March; AMJ: April-June; JAS: July-September; OND: October-December.

this rainfall comes immediately prior to a dry spell from January to March. The correlation from 1943 to 1993 is diminished $(r=0.36)$, but it is still significant at the $99 \%$ confidence level. The slight decline of October to December correlation in this period is due to less frequent ENSO activity in the mid 20th century. Indeed, the correlation for the period from 1969 to 1998 increases to 0.47. Overall, the October to December rainfall-ENSO correlation remains consistent with some natural variability in the 130 year long record. Note, that the correlation between October to December rainfall with the previous season's NINO3 (July to September) and that of two seasons prior (April to June) are both significant at the $99 \%$ level $(r=0.35$ and 0.34 respectively).

3.1.2. January to September. The rainfall-ENSO correlations during each quarter from January to September were weaker than those during the October to December quarter (Table II). There has also been considerable decadal variability in the ENSO-rainfall relationships during these three quarters (January-March, April-June, July-September) as evident from the comparison of the correlations for the last 50 years and the last 130 years (Table II). 
Although the ENSO relationship with rainfall and streamflow does show decadal modulation in the first three quarters, the relationship for the aggregate duration remains more stable. This is because, on average, rainfall declines with El Niño from January to September (save in May). As described in Section 3.2, streamflow also declines with El Niño in all months from January to September. Another reason to consider the ENSO influences on the aggregate January to September rainfall is because it assists in interpretation of ENSO influences on streamflow.

The aggregate January to September rainfall shows a relationship ( $r=-0.44)$ with concurrent NINO3 that is significant at the 99\% level. This result held from 1869 to 1998 and from 1943 to 1993. More robust methods, such as rank correlations, yielded similar results as well (see Table IV). The aggregate January to September rainfall also shows a significant correlation at the $95 \%$ level with the previous season (October to December) NINO3 $(r=0.31)$.

3.1.3. Recent warm ENSO events. During the recent major ENSO warm events (1982-83, 1987-88, 1991-93, 1994-95 and 1997-98), there was a consistent and significant decline in rainfall during the January to September period. The relationship that we have portrayed for the October to December period, of increasing rainfall with El Niño, held only during 1982, 1994 and 1998. There were modest declines in October to December rainfall during 1987 and 1991. This underlines the need to consider other predictors, such as those based on the Indian Ocean.

\subsection{Analysis of streamflow in the Upper Mahaweli}

The influences of ENSO on streamflow during El Niño, La Niña and normal phases was represented by conditionally averaging the streamflow in periods where the NINO3 index was above $0.5^{\circ} \mathrm{C}$, below $-0.5^{\circ} \mathrm{C}$ or in between respectively (Figure 5). A striking feature of Figure 5 is that the streamflow during El Niño episodes is lower for all months from January to September than during either La Niña or normal phases. The January to September streamflow during the El Niño phase is less by $30 \%$, on average, than that during the La Niña phase. However, the aggregate October to December streamflow in the El Niño phase was higher, on average, by $10 \%$ than that during the La Niña phase.

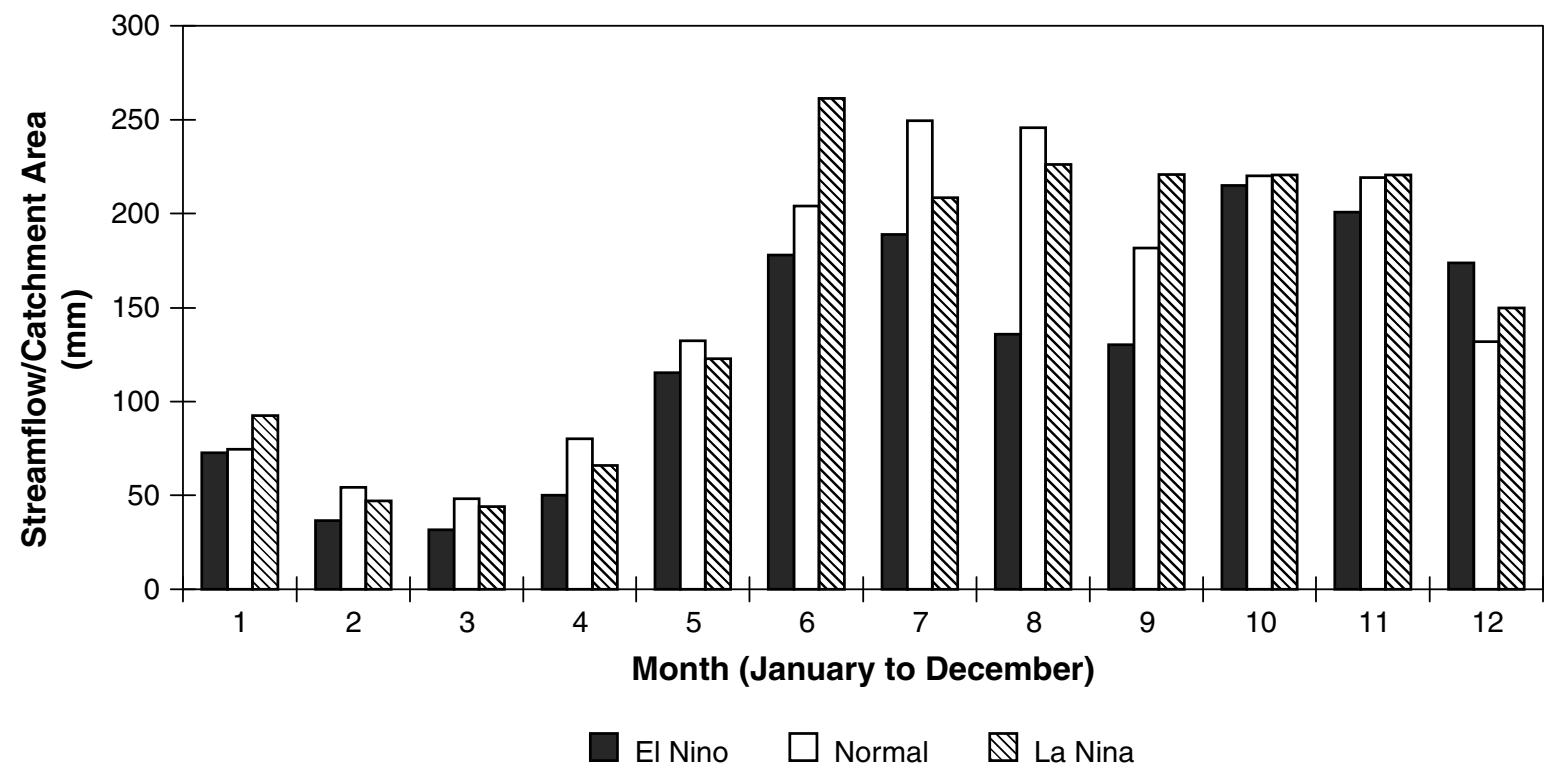

Figure 5. The average monthly streamflow at Peradeniya normalized by its catchment area along the Mahaweli river in Sri Lanka during the El Niño, La Niña and normal phases 
Table III. Seasonal characteristics of aggregate streamflow from January to September and from October to December at Peradeniya are tabulated. Significant correlations at the $99 \%$ and $95 \%$ levels are 0.36 and 0.28 respectively $(n=51)$. Correlations that are significant at the $95 \%$ level are shown in bold

\begin{tabular}{|c|c|c|c|c|c|c|c|c|c|}
\hline \multirow[t]{2}{*}{ Station } & \multirow{2}{*}{\multicolumn{3}{|c|}{$\begin{array}{c}\text { Average streamflow }\left(10^{6} \mathrm{~m}^{3}\right) \\
\text { [standard deviation] }\end{array}$}} & \multicolumn{6}{|c|}{ Correlation with NINO3.4 } \\
\hline & & & & \multicolumn{2}{|c|}{$1943-93$} & \multicolumn{2}{|c|}{$1943-68$} & \multicolumn{2}{|c|}{$1968-93$} \\
\hline Talawakelle & $\begin{array}{l}\text { Jan. }- \text { Dec. } \\
449 \text { [157] }\end{array}$ & $\begin{array}{l}\text { Jan.-Sep. } \\
310\end{array}$ & Oct.-Dec. & $\begin{array}{c}\text { Jan. }- \text { Sep. } \\
-0.46\end{array}$ & $\begin{array}{l}\text { Oct.-Dec. } \\
0.09\end{array}$ & $\begin{array}{c}\text { Jan. }- \text { Sep. } \\
-0.32\end{array}$ & $\begin{array}{l}\text { Oct. }- \text { Dec. } \\
-0.23\end{array}$ & $\begin{array}{c}\text { Jan. }- \text { Sep. } \\
\quad-0.65\end{array}$ & $\begin{array}{l}\text { Oct.-Dec. } \\
-0.09\end{array}$ \\
\hline Peradeniya & 2073 [644] & 1393 [452] & 679 [230] & -0.52 & 0.03 & -0.05 & -0.20 & -0.69 & -0.07 \\
\hline
\end{tabular}

The modulation of streamflow due to ENSO during October to December is not as clear cut as for rainfall. Overall, the differences among the monthly average rainfall and streamflow in different ENSO phases show a considerable modulation of streamflow by hydrological processes, such as groundwater recharge and discharge.

The aggregate annual streamflow anomalies are shown in the top panel of Figure 6, along with the average annual NINO3.4 values. The annual streamflow at Peradeniya shows a modest correlation $(r=-0.32)$ with the annual NINO3 for the period from 1943 to 1993 (Table III). However, the January to September streamflow shows a more significant correlation $(r=-0.52)$ with NINO3.4. This relationship has become stronger in recent decades (Table IV and Figure 6). The ENSO-streamflow relationship for the season from October to December is insignificant $(r=0.06)$.

Streamflow management affected none of these relationships significantly. These relationships hold for both the unmanaged sub-catchments and for the period prior to the impoundment of the Mahaweli at Kotmale. The relationships identified with correlation analysis were preserved even when robust methods such as rank correlations were used or when the correlations were computed after removing the long-term declining trend in the streamflow record (Table IV). The long-term decline in streamflow is thus unrelated to the ENSO phenomenon.

A contingency table is presented in Table $\mathrm{V}$ showing the prevalence of three terciles for aggregate January to September streamflow for El Niño, La Niña and normal phases. The streamflow terciles are referred to as 'below-normal', 'near-normal' and 'above-normal'. El Niño, normal and La Niña phases are identified following Trenberth (1997). The contingency table shows a shift in the distribution of streamflow during the El Niño and La Niña episodes. During El Niño events, the below-normal category is preferred, whereas during La Niña the above-normal category is preferred.

Heidke skill scores are used to provide some measure of forecast quality based on the contingency table. The Heidke skill score is a measure of forecast skill that is widely used when the forecasts and corresponding

Table IV. Seasonal breakdown of streamflow at Peradeniya based on records from 1953 to 1993. Significant correlations at $99 \%$ and $95 \%$ levels are 0.36 and 0.28 respectively for records from 1943 to $1993(n=51)$. For the shorter record (1953-93), the significance levels at $99 \%$ and $95 \%$ are 0.41 and 0.31 . Correlations that are significant at the $95 \%$ level are shown in bold

\begin{tabular}{|c|c|c|c|c|c|}
\hline Characteristic & JFM & AMJ & JAS & OND & Annual total \\
\hline Mean streamflow $\left(10^{6} \mathrm{~m}^{3}\right)$ & 197 & 476 & 719 & 679 & 2073 \\
\hline Standard deviation $\left(10^{6} \mathrm{~m}^{3}\right)$ & 86 & 252 & 263 & 230 & 588 \\
\hline \multicolumn{6}{|l|}{ Correlation with NINO3 } \\
\hline $1943-93$ & -0.15 & -0.22 & -0.32 & 0.01 & -0.34 \\
\hline $1953-93$ & -0.29 & -0.35 & -0.45 & 0.00 & -0.44 \\
\hline Rank correlation with NINO3 (1943-93) & -0.16 & -0.16 & -0.39 & 0.02 & -0.33 \\
\hline Correlation with SOI ${ }^{\mathrm{a}}(1953-93)$ & 0.13 & 0.13 & 0.50 & -0.04 & 0.34 \\
\hline
\end{tabular}

${ }^{\text {a }}$ SOI: Southern oscillation index. 

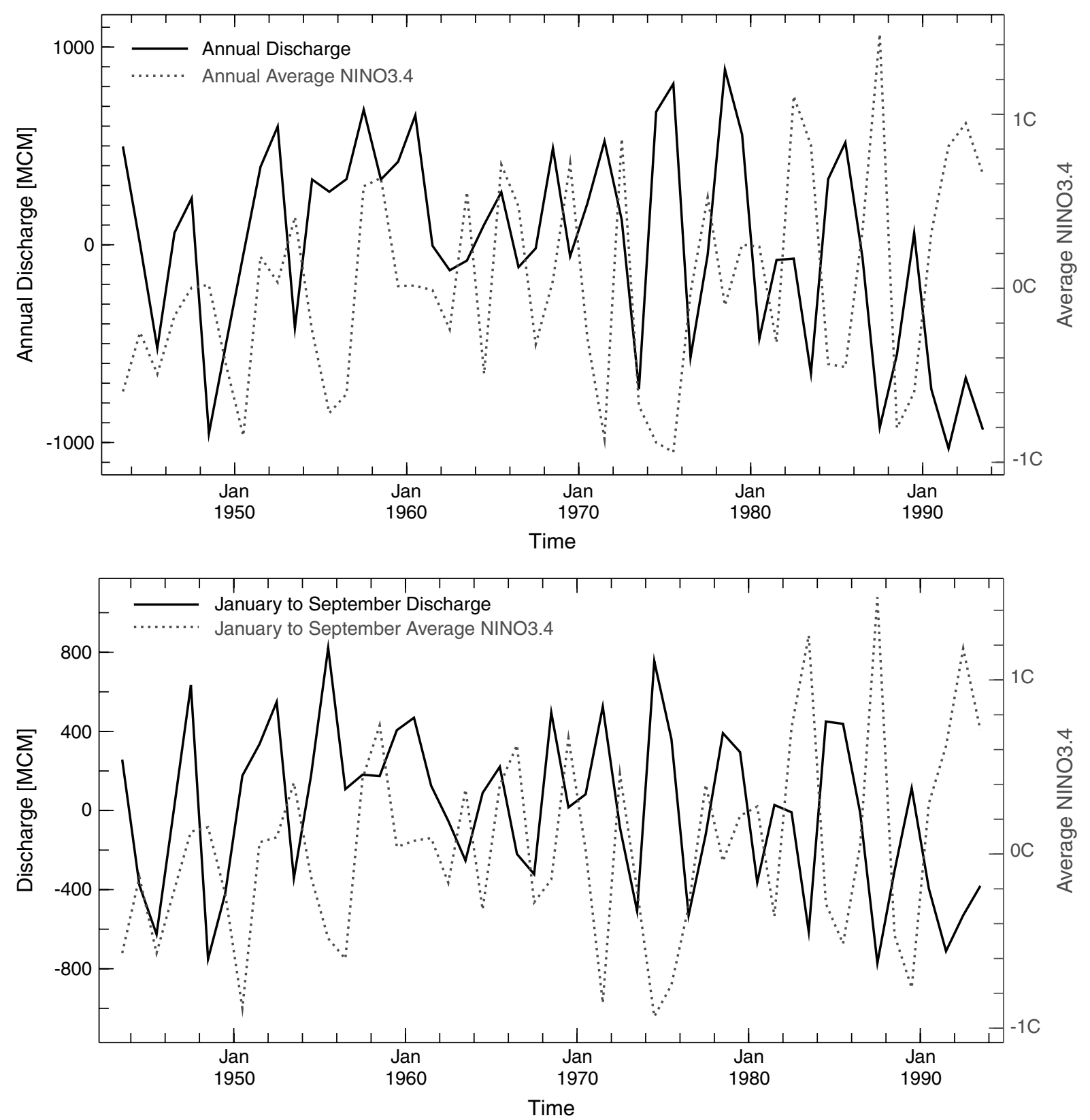

Figure 6. The time series of annual streamflow (or discharge) anomalies at Peradeniya and the annual average NINO3 index are shown in the top panel. The time series of aggregate January to September streamflow anomalies and the average January to September NINO3 index are shown in the bottom panel

observations are expressed in categories such as below-normal, near-normal and above-normal (Wilks, 1995). The score is based on the number of forecasts where the category with the largest forecasted probability turned out to be correct. The skill $S$ is given by $S=100(C-E) /(N-E)$, where $C$ is the number of correct forecasts, $E$ is the number of correct forecasts expected by chance and $N$ is the total number of forecasts. With three categories, the formula reduces to $S=150[(C / N)-(1 / 3)]$. An all-correct forecast results in a score of 100 , whereas a forecast with as many correct as expected by chance scores zero. The values may be negative too. The Heidke score, although simple, has its drawbacks: it does not penalize two-category 
Table V. Contingency table for the association of NINO3.4 with aggregate January to September streamflow between 1943 and 1993. The ENSO phases are defined as follows: El Niño (NINO3.4 $>0.4^{\circ} \mathrm{C}$ ); normal $\left(-0.4^{\circ} \mathrm{C}>\mathrm{NINO} .4>0.4^{\circ} \mathrm{C}\right.$ ) and La Niña (NINO3.4 $<-0.4^{\circ} \mathrm{C}$ ). The streamflow terciles are demarcated as 'below-normal' (streamflow $<1197 \times$ $\left.10^{6} \mathrm{~m}^{3}\right)$, 'near-normal' $\left(1197<\right.$ streamflow $\left.<1563 \times 10^{6} \mathrm{~m}^{3}\right)$ and 'above-normal' (streamflow $>1563 \times 10^{6} \mathrm{~m}^{3}$ )

\begin{tabular}{lccc}
\hline NINO3.4 & \multicolumn{3}{c}{ Streamflow } \\
\cline { 2 - 4 } & Below-normal tercile & Near-normal tercile & Above-normal tercile \\
\hline El Niño $(>0.4)$ & 6 & 4 & 2 \\
Near normal & 7 & 9 & 8 \\
La Niña $(<-0.4)$ & 2 & 3 & 5 \\
\hline
\end{tabular}

errors (that is the occurrence of below-normal when above-normal was predicted and vice versa), nor does it discriminate among probabilistic forecasts for different categories.

A forecast based on ENSO alone would associate El Niño with below-normal streamflow, normal ENSO phase with near-normal streamflow, and La Niña with above-normal streamflow. Accordingly, for Table V, $C=20$ and $N=46$. The resulting Heidke score is 15 . This score, though modest, is still significant. Indeed, the number of two-category errors is fewer than $10 \%$.

\section{DISCUSSION AND CONCLUSIONS}

This work has identified a clear relationship between various ENSO indices and rainfall and streamflow in the Upper Mahaweli catchment. El Niño conditions are associated with lower average rainfall and streamflow and La Niña with the converse. This association is more pronounced for both rainfall and streamflow when the period from January to September alone is considered. In contrast to this relationship, the ENSO influence on rainfall during the remaining season (October to December) is in the opposite sense. However, the influence on the streamflow from October to December is ambiguous. The relationship between streamflow and ENSO indices shows some decadal variability, with the relationship becoming stronger in recent decades.

The relationship between ENSO indices, rainfall and streamflow is quite significant from January to September, and this relationship can contribute to a useful prediction scheme based on reliable ENSO forecasts. Even though there is little direct correlation between October to December streamflow and NINO3, the significant correlation between NINO3 and rainfall during this period can be exploited for streamflow predictions by using a hydrological model. Monitored hydrological conditions in the catchment and rainfall predictions for October to December during the summer can be used as input for a hydrological model that can predict the October to December streamflow. Future investigations of influences of other climatic precursors, such as Indian Ocean conditions and Eurasian snow cover on streamflow and rainfall, should help to improve the prediction scheme.

Even an improved prediction scheme will be inadequate occasionally, and water-resources managers and others who use them should be well aware of such a scheme's limitations. The challenge in the successful use of the forecasts is the communication of the uncertainty to users and the choice of policies that will minimize regret in case of failure.

This analysis has brought out significant differences in the ENSO influences on monthly precipitation and streamflow. This difference is brought about by the modulation of soil conditions, groundwater recharge and discharge from rainfall in previous months. This example shows that though teleconnections for ENSO with precipitation in a river catchment provide strong clues as to the ENSO relationship with streamflow, it is necessary to assess these relationships directly. Such assessments are particularly needed in locales with multiple rainy seasons with different dynamical processes associated with them. 
It has been previously surmised that the ENSO influences on streamflow in Asia and Africa are, at most, modest. The present investigation, and those of Wang and Eltahir (1999), Amarasekera et al. (1997), Kahya and Karabork (2001) and Whitaker et al. (2001), show that examination of ENSO influences based on streamflow records for individual river basins, appropriately stratified by seasons, can indeed bring out useful relationships that may not be evident based on streamflow data that is averaged on a rectangular grid.

\section{ACKNOWLEDGEMENTS}

Data used in this study were obtained from the Department of Irrigation, Department of Meteorology and the Mahaweli Authority in Sri Lanka. Much of the climatic analysis is based upon work conducted with Chet Ropelewski. Detailed comments by the anonymous referees were valuable in improving this paper. This work was supported by a fellowship at the International Research Institute for Climate Prediction administered by the University Consortium for Atmospheric Research.

\section{REFERENCES}

Allan R, Lindesay J, Parker D. 1996. El Niño/Southern Oscillation and Climate Variability. CSIRO Press: Collingwood, Australia. Amarasekera NA, Lee RF, Williams ER, Eltahir EAB. 1997. ENSO and the natural variability in the flow of tropical rivers. Journal of Hydrology 200: 24-39.

Cane MA, Zebiak SE. 1985. Experimental forecasts of El Niño. Nature 321: 827-832.

Dettinger MD, Diaz HF. 2000. Global characteristics of stream flow seasonality and variability. Journal of Hydrometeorology 1(4): 289-310.

Dettinger MD, Cayan DR, McCabe GJ, Marengo JA. 2000. Multiscale streamflow variability associated with El Niño/southern oscillation. In El Niño and the Southern Oscillation: Multiscale Variability and Global and Regional Impacts, Diaz HF, Markgraf V (eds). Cambridge University Press: Cambridge, UK.

Dracup JA, Kahya E. 1994. The relationships between U.S. streamflow and La Niña events. Water Resources Research 30(7): $2133-2141$.

Goddard L, Mason SJ, Zebiak SE, Ropelewski CF, Basher R, Cane MA. 2001. Current approaches to seasonal to inter-annual climate predictions. International Journal of Climatology 21: 1111-1152.

Kahya E, Dracup JA. 1993. U.S. streamflow patterns in relation to the El Niño/southern oscillation. Water Resources Research 29(8): $2491-2503$.

Kahya E, Karabork MC. 2001. The analysis of El Niño and La Niña signals in streamflows of Turkey. International Journal of Climatology 21: 1231-1250.

Kaplan A, Cane MA, Kushnir Y, Clement AC, Blumenthal MB, Rajagopalan B. 1998. Analyses of global sea surface temperature: 1856-1991. Journal of Geophysical Research 103: 18 567-18589.

Krishna Kumar K, Kleeman R, Cane MA, Rajagopalan B. 1999a. Epochal changes in Indian monsoon-ENSO precursors. Geophysical Research Letters 26(1): 75-78.

Krishna Kumar K, Rajagopalan B, Cane MA. 1999b. On the weakening relationship between the Indian monsoon and ENSO. Science 284: $2156-2159$.

NEDECO 1979. Mahaweli Ganga development program implementation strategy study, Volume 2. Ministry of Mahaweli Development, Colombo.

Piechota T, Dracup JA. 1996. Drought and regional hydrologic variation in the United States: associations with El Niño/southern oscillation. Water Resources Research 32(5): 1359-1373.

Piechota TC, Dracup JA, Chiew FHS, McMahon TA. 1997. Seasonal streamflow forecasting in eastern Australia and the El Niño-southern oscillation. Water Resources Research 34: 3035-3044.

Piper BS, Sutcliffe JV, Parks YP. 1994. The Victoria Project Sri Lanka: hydrological analysis for Victoria Dam. Proceedings of the Institution of Civil Engineers, Water, Maritime and Energy Journal 106: 43-52.

Puvaneswaram KM, Smithson DA. 1993. Controls on the precipitation distribution in Sri Lanka. Theoretical and Applied Climatology 47: $105-115$.

Rasmussen EM, Carpenter TH. 1983. The relationship between eastern equatorial Pacific sea surface temperature and rainfall over India and Sri Lanka. Monthly Weather Review 110: 354-384.

Ropelewski CF, Halpert MS. 1987. Global and regional scale precipitation patterns associated with the El Niño/southern oscillation. Monthly Weather Review 115: 1606-1626.

Ropelewski CF, Halpert MS. 1989. Precipitation patterns associated with the high index phase of the southern oscillation. Journal of Climate 2: 268-284.

Ropelewski CF, Jones PD. 1987. An extension of the Tahiti-Darwin southern oscillation index. Monthly Weather Review 115: 2161-2165.

Simpson HJ, Cane MA, Herczeg AL, Simpson JH. 1993. Annual river streamflows in southeastern Australia related to the El Niño southern oscillation forecasts of sea surface temperatures. Water Resources Research 29(11): 3671-3680.

Suppiah R. 1989. Relationship between the southern oscillation and the rainfall of Sri Lanka. International Journal of Climatology 9: 601-618.

Suppiah R. 1996. Spatial and temporal variations in the relationships between the southern oscillation phenomenon and the rainfall of Sri Lanka. International Journal of Climatology 16: 1391-1407. 
Suppiah R. 1997. Extremes of the southern oscillation phenomenon and the rainfall of Sri Lanka. International Journal of Climatology 17: $87-101$.

Trenberth KE. 1997. The definition of El Niño. Bulletin of the American Meteorological Society 78(12): 2771-2777.

Uvo CB, Graham NE. 1998. Seasonal runoff forecasts for northern South America: a statistical model. Water Resources Research 34(12): $3515-3524$.

Wang G, Eltahir EAB. 1999. Use of ENSO information in medium and long-range forecasting of Nile floods. Journal of Climate 12: 1726-1737.

Whitaker DW, Wasimi SA, Islam S. 2001. The El Niño southern oscillation and long-range forecasting of the flows in the Ganges. International Journal of Climatology 21: 77-87.

Wickramagamage P. 1998. Large-scale deforestation for plantation agriculture in the hill country of Sri Lanka and its impacts. Hydrological Processes 12: 2015-2028.

Wilks DS. 1995. Statistical Methods in Atmospheric Sciences. Academic Press: San Diego, USA.

Zubair L. 2001. El-Niño-southern oscillation influences on rice production in Sri Lanka. International Journal of Climatology 22: $249-260$. 